\title{
Pengaruh Perilaku Inovatif terhadap Kompetensi Manajerial Kepala Sekolah Dasar di Kabupaten Labuhan Batu
}

\author{
${ }^{1 *}$ Marlina Siregar, ${ }^{2}$ Benyamin Situmorang, ${ }^{1 R}$. Rohana, 1 Panggih Nur Adi, ${ }^{1}$ Mila \\ Nirmala Sari Hasibuan, ${ }^{1}$ Reni Kartikaningsih
}

${ }^{1}$ Program Studi Pendidikan Pancasila dan Kewarganegaraan, Universitas Labuhan Batu, Jl. SM. Raja

KM. 12,5 No. 126A Bakaran Batu Rantau Prapat, Labuhanbatu-Sumut, 21418, Indonesia

2Program Studi Pendidikan Pancasila dan Kewarganegaraan, Universitas Negeri Medan, Jl. William Iskandar Ps. V, Kenangan Baru, Kabupaten Deli Serdang, Sumatera Utara 20221, Indonesia

*Corresponding Author e-mail: siregarmarlina447@gmail.com

Received: March 2020; Revised: April 2020; Published: July 2020

\begin{abstract}
Abstrak
Penelitian ini bertujuan untuk menggambarkan pola hubungan antar variabel yang dilibatkan berdasarkan data empirik yang dikumpulkan dengan menggunakan instrumen yang dikembangkan. Penelitian ini merupakan penelitian kualitatuf yang dilaksanakan di Kabupaten Labuhanbatu selama 4 (empat) bulan terhitung mulai Juli 2019 hingga Oktober 2019. Adapun Populasi target dalam penelitian ini adalah kepala Sekolah Dasar Negeri di Kabupaten Labuhanbatu sebanyak 241 sekolah. Instrumen yang digunakan mengumpulkan data variabel perilaku inovatif, dikembangkan dan diuji cobakan terlebih dahulu untuk menguji validitas dan reliabilitasnya sedangkan variabel kompetensi manajerial kepala sekolah menggunakan instrumen yang telah ada yang diambil dari dokumen milik Dinas Pendidikan sehingga tidak dilakukan uji validitas dan reliabilitas. Hasil dari penelitian ini diketahui dari hasil olah data perilaku inovatif kepala sekolah diperoleh nilai Mean $=68.37$ dan Standar Deviasi $=13.739$. Untuk mengidentifikasi kecenderungan atau pengkategorian tingkatan perilaku inovatif kepala sekolah berdasarkan nilai mean dan standar deviasi. Berdasarkan hasil penelitian dapat disimpulkan bahwa Perilaku Inovatif berpengaruh terhadap Kompetensi Manajerial.

Kata kunci: Perilaku inovatif, Kompetensi manajerial, Kepala sekolah

\section{The Effect of Innovative Behavior on Managerial Competence of Primary School Principals in Labuhan Batu District}

\begin{abstract}
This study aims to describe the pattern of relationships between variables involved based on empirical data collected using the developed instrument. This research is a quality study conducted in Labuhanbatu Regency for 4 (four) months from July 2019 to October 2019. The target population in this study is the Principal of State Elementary Schools in Labuhanbatu Regency as many as 241 schools. The instrument used to collect innovative behavioral variable data was developed and tested first to test its validity and reliability while the managerial competency variable of principals used existing instruments taken from documents belonging to the Department of Education so that validity and reliability tests were not carried out. The results of this study are known from the results of the school principal's innovative behavior data obtained by the Mean value $=68.37$ and Standard Deviation $=13.739$. To identify trends or categorizing the level of innovative behavior of principals based on the mean and standard deviation. Based on the results of this study concluded that innovative behavior affects managerial competence.
\end{abstract}

Keywords: Innovative Behavior, Managerial Competence, Primary School Principals

How to Cite: Siregar, M., Situmorang, B., Rohana, R., Adi, P., Hasibuan, M., \& Kartikaningsih, R. (2020). Pengaruh Perilaku Inovatif terhadap Kompetensi Manajerial Kepala Sekolah Dasar di Kabupaten Labuhan Batu. Jurnal Penelitian dan Pengkajian Ilmu Pendidikan: e-Saintika, 4(2), 119-125. doi:https:// doi.org/10.36312/e-saintika.v4i2.190 


\section{PENDAHULUAN}

Sekolah adalah organisasi yang bergerak dibidang pendidikan dalam kerangka pendidikan nasional. Sebagai organisasi sekolah bertujuan untuk mencapai tujuan yg sudah ditetapkan baik tujuan kurikuler, institusi dan tujuan nasional yang sudah ditetapkan pemerintah.Untuk mencapaai tujuan yang nasional dibutuhkan sumberdaya manusia seperti kepala sekolah, pendidik dan tenaga kependidikan bertanggung jawab dalam tugasnya masing masing.

Peraturan Menteri Pendidikan Nasional Nomor 13 Tahun 2007 mengenai standar Kepala Sekolah/Madrasah ditetapkan bahwa ada lima kompetensi yaitu : Kepribadian, Manajerial, Kewirausahaan, Supervisi dan Sosial. Dikeluarkannya PermenDiknas Nomor 13 Tahun 2007 mengenai Standar Kepala Sekolah/Madrasah,berdampak pada kepala sekolah sebagai pimpinan tertinggi di sekolah harus memiliki lima dimensi kompetensi, yaitu dimensi kompetensi kepribadian, manajerial, kewirausahaan, supervisi, dan sosial. Operasionalisasi PP Nomor 13 tahun 2007 tersebut diatur melalui Peraturan Menteri Pendidikan Nasional Nomor 28 Tahun 2010 dalam Penugasan Guru sebagai Kepala Sekolah/ Madrasah yang menjelaskan syarat-syarat dan tahapan yang wajib dilalui guru agar diberi tugas tambahan sebagai kepala sekolah/madrasah (Kemendiknas, 2011).

Menurut Mulyasa (2009) Kepala Sekolah adalah salah satu komponen pendidikan yang sangat menentukan untuk meningkatkan kualitas pendidikan, sebab kepala sekolah sebagai pengelola pendidikan pada tingkat sekolah. Oleh karena itu, kepala sekolah bertanggungjawab terhadap maju mundurnya sekolah.

Berdasarkan hal tersebut seyogyanya kepala sekolah harus mempunyai kemampuan dan keterampilan dalam mendukung ketercapaian kinerja dirinya sebagai seorang kepala sekolah. Banyaknya beban kerja dapat diselesaikan kepala sekolah dan bahkan bisa jadi menghasilkan prestasi kerja yang baik jika kepala sekolah memiliki kemampuan maupun keterampilan yang dapat mendukung kesuksesan kepala sekolah dalam menjalankan tugas. Kemampuan maupun keterampilan yang dimaksud adalah kemampuan kepala sekolah melakukan perilaku inovatif, kemampuan dan keterampilan ini akan mendukung seorang kepala sekolah untuk dapat menampilkan kompetensi manajerial yang maksimal. Kepala sekolah banyak mengeluhkan bahwa mereka kekurangan dana untuk mengadakan kegiatan pelatihan disekolah dan mengikutsertakan guru pada pelatihan-pelatihan. Untuk mengatasi ini diharapkan pimpinan sekolah menerapkan kompetensi wirausaha yaitu memiliki kemampuan berpikir inovatif. Ketika melaksanakan prinsip kewirausahaan yang dikaitkan untuk meningkatkan kompetensi guru, maka pimpinan seharusnya menciptakan pembaharuan, keunggulan komparatif, dan menggunakan berbagai peluang. Pimpinan sekolah dengan sikap kewirausahaan yang kuat mampu melakukan perubahan yang inovatif di sekolahnya, baik perubahan yang berkaitan dengan pembelajaran siswa maupun kompetensi gurunya.

Pimpinan diharapkan memiliki kemampuan berperilaku inovatif sehingga bermanfaat untuk kemajuan sekolah, berupaya keras mencapai kemajuan sekolah agar menjadi sekolah yang efektif, memiliki komitmen untuk maju dan sukses dalam menjalankan tugas pokok dan fungsinya sebagai kepala sekolah tidak putus asa dan serta mencari jalan keluar yang paling baik untuk menghadapi masalah yang ada di sekolah, mempunyai kemampuan kewirausahaan untuk menjalankan kegiatan di sekolah sebagai sumber belajar peserta didik (Manap, Hartuti, Djuwita, Komaruddin, \& Alperi, 2010) 
Selain kemampuan berperilaku inovatif, pemimpin sekolah hendaknya juga trampil menerapkan sistem manajemen maupun kepemimpinan yang kreatif. Tata kelola yang kreatif serta kemampuan menyelesaikan masalah dibutuhkan dari seorang pemimpin.oleh karena itu setiapkepala sekolah harus mampu berperilaku kreatif untuk meningkatkan kualitas proses pembelajaran,meningkatkan kualitas kurikulum, kualitas guru, peningkatan pembiayaan, penyediaan fasilitas serta membentuk kepribadian dan keterampilan siswa. (Darmawan, 2012). Menurut Siswandi (Luthfita, 2016) pimpinan mempunyai peran besar untuk mengkoordinasikan dan menselaraskan semua sumberdaya yang ada di sekolah untuk mencaapai tujuan yang sudah di tetapkan melalui program yang akan dilaksanakan. Pemimpin harus memiliki kompetensi manajerial yang baik sehingga dapat mengambil inisiatif serta prakarsa agar mutu sekolah meningkat.Langkah yang harus dilakukan untuk melakukan perubahan adalah melalui penerapan prilaku inovatif di sekolah itu sendiri. Berdasarkan hal diatas, maka perlu di teliti perilaku inovati kepala sekolah di dalam meningkatkan kompetensi kepala sekolah

\section{METODE}

Penelitian ini merupakan penelitian kuantitatif yang bertujuan untuk menggambarkan pola hubungan setiap variabel berdasarkan data empirik yang dikumpulkan dengan menggunakan instrumen yang dikembangkan. Penelitian ini dilaksanakan di Kabupaten Labuhanbatu selama empat bulan terhitung mulai Juli 2019 hingga Oktober 2019. Adapun Populasi penelitian ini adalah Kepala Sekolah Dasar Negeri di Kabupaten Labuhanbatu sebanyak 241 sekolah. Dengan demikian, jumlah populasi terjangkau dalam penelitian ini sebanyak 241 orang Kepala Sekolah, sedangkan untuk sampel penelitian diambil sebahagian dari populasi target setiap Kecamatan, dengan mempertimbangkan masa kerja jabatan, pendidikan dan kepangkatan. Sampel penelitian disajikan pada Tabel 1 berikut.

Tabel 1. Distribusi Kepala Sekolah Tiap Kecamatan sebagai Populasi dan Sampel

\begin{tabular}{llcc}
\hline No & Nama Kecamatan & $\begin{array}{c}\text { Jumlah kepala sekolah } \\
\text { (sebagai Populasi) }\end{array}$ & $\begin{array}{c}\text { Jumlah kepala sekolah } \\
\text { (sebagai Sampel) }\end{array}$ \\
\hline 1 & Rantau Utara & 25 & 15 \\
2 & Bilah Hulu & 45 & 26 \\
3 & Panai Tengah & 23 & 14 \\
4 & Panai Hilir & 23 & 14 \\
5 & Bilah Barat & 29 & 17 \\
6 & Bilah Hilir & 29 & 17 \\
7 & Rantau Selatan & 19 & 11 \\
8 & Pangkatan & 26 & 15 \\
9 & Panai Hulu & 22 & 13 \\
\hline Jumlah & 241 & 142 \\
\hline
\end{tabular}

Sumber: Dapo.dikdasmen.kemdikbud.go.id untuk semester ganjil 2019/2020

Penelitian dilaksanakan melalui beberapa tahapan seperti (1) melakukan tinjauan lapangan (pra-survei), untuk mengetahui keadaan lapangan, (2) menentukan jumlah sampel penelitian sebagai sumber data yang mewakili populasi, (3) mengembangkan instrumen penelitian, menguji coba instrument penelitian untuk mengetahui tingkat validitas dan reliabilitas instrument, mengurus ijin melakukan penelitian, mengumpulkan data penelitian melalui pelaksanaan uji dan penyebaran 
angket, memvalidasi data penelitian, menelaah data penelitian, menyimpulkan hasil penelitian dan mempresentasikan hasil penelitian.

Variabel dalam penelitian ini ada dua yaitu kompetensi manajerial dan perilaku inovatif. Adapun yang menjadi variabel eksogen dalam hal ini adalah Perilaku Inovatif dari Kepala Sekolah. Kompetensi manajerial dari Kepala Sekolah merupakan variabel endogen. Secara konseptual Perilaku Inovatif dari kepala sekolah adalah seluruh tindakan yang dilakukan kepala sekolah untuk menghasilkan, memperkenalkan serta menerapkan sesuatu yang berguna, sedangkan secara operasional Perilaku inovatif Inovatif Kepala Sekolah didefenisikan didefinisikan sebagai skor yang diperoleh kepala sekolah dalam kemampuannya melakukan 1) peluang untuk berinovasi, 2) memmunculkan konsep untuk pengembangan 3) melakukan peninjauan terhadap idetersebut, 4) usaha untuk merealisasikan ide 5) menguji dan mengkomersilkan ide inovatif

Instrumen yang digunakan untuk mengumpulkan data variabel perilaku inovatif, dikembangkan dan diuji cobakan terlebih dahulu untuk menguji validitas item no 14 dengan taraf signifikansi 0.008 dan dari hasil perhitungan reliabilitas instrumen, soal dinyatakan realiable apabila $r_{\text {hitung }}>r_{\text {tabel. }}$. Unutuk melakukan perhitungan digunakan Program IBM SPSS 25, dengan hasil analisis menunjukkan bahwa instrumen ini adalah reliabel dengan koefisien Cronbach Alpa =0, $911(>0,6)$ sedangkan variabel kompetensi manajerial kepala sekolah menggunakan instrumen yang telah ada yang diambil dari dokumen Dinas Pendidikan sehingga tidak dilakukan uji validitas dan reliabilitas. Ada tiga jenis perangkat yang dikembangkan yaitu angket lembar observasi serta lembar penilaian. Angket digunakan menjaring data tentang Perilaku Inovatif Sementara lembar observasi digunakan untuk mendapatkan kemampuan manajerial dari kepala sekolah.

Intrumen Kompetensi Manajerial dari kepala sekolah dikembangkan berdasarkan dari 5 indikator yang dijabarkan dalam bentuk pernyataan sebanyak 76 item dengan sistem penilaian seperti disajikan pada Tabel 2 dan Tabel 3 sebagai berikut.

Tabel 2. penilaian kompetensi manajerial kepala sekolah

\begin{tabular}{ll}
\hline Skor & Keterangan \\
\hline 4 & Kepala Sekolah melaksanakan/melakukan semua kriteria dalam indicator \\
3 & $\begin{array}{l}\text { yang disebutkan (Baik sekali/selalu) } \\
\text { Kepala Sekolah melaksanakan/melakukan sebagian besar kriteria dalam } \\
\text { indicator yang disebutkan (baik/sering) }\end{array}$ \\
2 & $\begin{array}{l}\text { Kepala Sekolah melaksanakan/melakukan sebagian kecil kriteria dalam } \\
\text { indicator yang disebutkan (Cukup/Kadang-kadang) }\end{array}$ \\
& $\begin{array}{l}\text { Kepala Sekolah tidak melaksanakan/melakukan semua kriteria dalam } \\
\text { indicator yang disebutkan (Kurang/Tidak) }\end{array}$ \\
\hline
\end{tabular}

Tabel 3. Kisi-kisi Instrumen Kompetensi Manajerial kepala sekolah

\begin{tabular}{lll}
\hline No & Indikator & Nomor Item Pernyataan \\
\hline 1 & Perencanaan & $1,2,3,4,5,6,7$ \\
2 & Kepemimpinan & $8,9,10,11,12,13,14,15,16,17,18,19$ \\
3 & Pengorganisasian & $20,21,22,23,24,25,26,27,28$ \\
4 & Penggerakan & $29,30,31,32,33,34,35,36,37,38,39,40,41,42,43,44,45$, \\
& & $46,47,48,49,50,51,52,53,54,55,56,57,58,59,60,61,62$, \\
& & $63,64,65,66,67,68,69,70,71$ \\
5 & Pengawasan & $72,73,74,75,76$ \\
\hline
\end{tabular}


Teknik Pengumpulan Data dikumpulkan dengan cara menilai kinerja kepala sekolah menengah pertama di Kabupaten Labuhanbatu, dengan menggunakan lembar penilaian kinerja dari Kemendiknas. Data kompetensi manajerial dikumpulkan dengan melakukan observasi dengan menggunakan lembar observasi penilaian kompetensi manajerial kepala sekolah dari Kemendiknas. Data perilaku inovatif, kemampuan komunikasi interpersonal dan pengembangan organisasi kepala sekolah dikumpulkan dengan cara menyebarkan angket kepada kepala sekolah menengah pertama di Kabupaten Labuhanbatu. Semua data yang terkumpul selanjutnya ditabulasi untuk selanjutnya dianalisis.

\section{HASIL DAN PEMBAHASAN}

Hasil penelitian yang didapatkan selanjutnya dikategorisasi berdasarkan skor yang didapatkan dari angket yang digunakan seperti disajikan pada Tabel 4 .

Tabel 4 Kategori Skor Capaian Variabel Perilaku Inovatif

\begin{tabular}{|c|c|c|c|c|}
\hline No & Kelompok Skor & Frekuensi Observasi & $\begin{array}{l}\text { Frekuensi } \\
\text { Relatif (\%) }\end{array}$ & Kategori \\
\hline 1 & $X \leq 47.76$ & 21 & 14.79 & Sangat rendah \\
\hline 2 & $47.76<X \leq 61.50$ & 13 & 9.15 & Rendah \\
\hline 3 & $61.50<X \leq 75.24$ & 72 & 50.70 & Cukup \\
\hline 4 & $75.24<X \leq 88.98$ & 20 & 14.08 & Tinggi \\
\hline 5 & $88.98 \overline{<} X$ & 16 & 11.27 & Sangat tinggi \\
\hline Total & & 142 & 10 & \\
\hline
\end{tabular}

Berdasarkan tabel 4 di atas diperoleh 50.70\% dari subjek penelitian, yaitu Kepala SD memiliki Perilaku Inovatif dalam kategori cukup, artinya tingkatan Perilaku Inovatif Kepala SD berada antara 41\% - 60\%. Dapat disimpulkan bahwa secara keseluruhan perilaku inovatif kepala SD dalam kategori cukup.

Tabel 5 Tingkat Kecenderungan Variabel Kompetensi Manajerial

\begin{tabular}{|c|c|c|c|c|}
\hline No & Kelompok Skor & Frekuensi Observasi & $\begin{array}{l}\text { Frekuensi } \\
\text { Relatif (\%) }\end{array}$ & Kategori \\
\hline 1 & $X \leq 129.95$ & 3 & 2.11 & Sangat rendah \\
\hline 2 & $129.9 \overline{5}<X \leq 177.9$ & 45 & 31.69 & Rendah \\
\hline 3 & $177.9<X \leq \overline{2} 21.36$ & 60 & 42.25 & Cukup \\
\hline 4 & $221.36<X<269.31$ & 15 & 10.56 & Tinggi \\
\hline 5 & $269.31<X$ & 19 & 13.38 & Sangat tinggi \\
\hline Total & & 142 & \multicolumn{2}{|c|}{100} \\
\hline
\end{tabular}

Berdasarkan Tabel 5 di atas ditunjukkan 42.25 persen dari subjek penelitian, yaitu Kepala SD memiliki Kompetensi Manajerial dalam kategori cukup, artinya tingkatan Kompetensi Manajerial Kepala SD berada antara 41\% - 60\%. Daapat disimpulkan bahwa secara keseluruhan kompetensi manajerial kepala SD kategori cukup.

Berdasarkan hasil pengujian hipotesis diperoleh koefisien jalur yang signifikan antara Perilaku Inovatif dengan Kompetensi Manajerial, yaitu: $\rho 31=0,421$. Selanjutnya, berdasarkan hasil perhitungan pengaruh proporsional diperoleh pengaruh langsung Perilaku Inovatif terhadap Kompetensi Manajerial sebesar 0,421. Dengan demikian, Perilaku Inovatif berpengaruh langsung positif terhadap Kompetensi Manajerial, yang mana $42.10 \%$ perubahan-perubahan Kompetensi 
Manajerial dapat ditentukan oleh Perilaku Inovatif. Kecermatan seorang kepala sekolah dalam memahami peraturan-peraturan tentu tergantung pada seberapa banyak informasi (pengetahuan) yang dimiliki dan sudah barang tentu keakuratan keputusan yang diambil, adalah tergantung pada tingkat pengetahuan yang dimiliki. Oleh karenanya semakin tinggi tingkat Perilaku Inovatif yang dimiliki kepala sekolah maka semakin mudah memahami segala kebijakan-kebijakan yang dituangkan dalam bentuk peraturan. Berdasarkan ini maka dapat diduga bahwa tingkat Perilaku Inovatif sekolah dari kepala sekolah mempengaruhi Kompetensi Manajerial secara positif dan signifikan.

\section{KESIMPULAN}

Berdasarkan hasil penelitian dapat disimpulkan bahwa perilaku inovatif berpengaruh terhadap kompetensi manajerial. Perilaku inovatif berpengaruh langsung positif terhadap kompetensi manajerial, yang mana $42.10 \%$ perubahanperubahan Kompetensi Manajerial dapat ditentukan oleh perilaku inovatif.

\section{SARAN}

Beberapa hal yang dapat disarankan kepada unsur yang terlibat dengan persekolahan yang berhubungan dengan hasil penelitian ini diantaranya (1) pemerintah kabupaten perlu secara berkesinambungan melakukan pengukuran kompetensi manajerial kepala sekolah melalui penilaian langsung bukan hanya berdasarkan data penilaian diri agar mutu pendidikan semakin baik, (2) masyarakat sekitar sekolah yang dalam hal ini Komitesekolah, diharapkan secara rutin dapat mendampingi kepala sekolah, dan berkontribusi untuk meningkatkan kompetensi manajerial kepala SD, dan (3) kepala SD diharapkan agar selalu memperbaharui dan meningkatkan pengetahuan dan keterampilan dalam pengelolaan sekolah melalui pelatihan maupun kegiatan formal dan non formal.dengan adanya teknologi informasi dan komunikasi yang baik saat ini menjadi wadah untuk mendapatkan gagasan inovatif dan untuk meningkatkan kompetensi diri.

\section{UCAPAN TERIMAKASIH}

Penelitian ini tidak menerima hibah khusus dari agensi pendanaan mana pun di sektor publik, komersial, atau nirlaba.

\section{DAFTAR PUSTAKA}

Aisyah, M. (2016). Kompetensi Manajerial Kepala Sekolah dalam Meningkatkan Kinerja Personil Sekolah pada SMP Negeri 1 Banda Aceh. Jurnal MUDARRISUNA: Media Kajian Pendidikan Agama Islam, 6(1), 143-158.

Bungai, J. (2016). Pengaruh Kompetensi Kepala Sekolah, Iklim Sekolah, dan Keefektifan Mengajar Terhadap Prestasi Lulusan SMA. Jurnal Ilmu Pendidikan, 13(2), 91-99.

Chayani, I.D., Karwanto (2013). Peran kepala sekolah sebagai manajer dalam upaya peningkatan kompetensi guru di SMA Unggulan Amanatul Ummah Surabaya. Jurnal. Digilib-UNS

Darmada, I. K., Dantes, N., \& Natajaya, N. (2013). Kontribusi Kompetensi Manajerial Kepala Sekolah, Iklim Kerja Dan Motivasi Kerja Terhadap Kinerja Guru SMP Negeri Se Kecamatan Mendoyo Kabupaten Jembrana (Doctoral dissertation, Ganesha University of Education). 
Depdiknas. (2003). Keputusan Menteri Pendidikan Nasional Nomor 162/U/2003 tentang Pedoman Penugasan Guru sebagai Kepala Sekolah, (Online), (http:/ / www.depdiknas.go.id, diakses 9 Maret 2018).

Depdiknas, (2007). Pendidikan dan Pelatihan : Kepemimpinan Kepala Sekolah Dalam Meningkatkan Sumber Daya Manusia di Sekolah Dasar. Jakarta : Direktorat Tenaga Kependidikan. Direktorat Jenderal Peningkatan Mutu Pendidik dan Tenaga Kependidikan. Depertemen Pendidikan Nasional.

Hadi, S. (2015). Kontribusi Kompetensi Emosional dan Praktik Kepemimpinan Transformasional Kepala Sekolah terhadap Keberdayaan Guru Sekolah Menengah Kejuruan. Jurnal Ilmu Pendidikan, 17(3), 1-16.

Irianto, J. (2007). Prinsip-Prinsip Dasar Manajemen Pelatihan : Dari Analisis Kebutuhan Sampai Evaluasi Program Pelatihan. Kajian Mandiri dan Pengembangan SDM. Bandung : Universitas Pendidikan Indonesia.

Jamali, A., L, D. Prasojo. (2013). Pengaruh Kompetensi Manajerial Kepala Sekolah, Lingkungan, Motivasi Guru, Terhadap Prestasi Siswa Sma Muhammadiyah Kota Yogyakarta. SMA Muhammadiyah 3 Yogyakarta

Krismastyanti, A. (2013). Kompetensi sosial kepala sekolah menengah atas negeri (SMAN) 105 Jakarta. Jurnal. Digilib-Universitas Gunadarma.

Manap, P. H., P. Djuwita., K., M. Alperi, (2010). Pemetaan Kompetensi Kepala SMP di Provinsi Bengkulu Dalam Rangka Peningkatan Kompetensi Berkelanjutan. Jurnal Ilmiah Manajemen Pendidikan Program Pascasarjana, 4(5), 82-95

Surjana, I, N.Y., N. Dantes2, I N. Natajaya. (2013). Kontribusi Supervisi Akademik, Kompetensi Manajerial Kepala Sekolah, Dan Motivasi Berprestasi Terhadap Kinerja Guru Sma Negeri Di Kabupaten Tabanan I. Program Studi Administrasi Pendidikan,Program Pascasarjana Universitas Pendidikan Ganesha Singaraja, Indonesia.

Rosalina, R. (2013). Persepsi Guru Tentang Kompetensi Manajerial Kepala Sekolah di Sekolah Dasar Negeri Kecamatan Padang Timur Kota Padang. Jurnal Administrasi Pendidikan, 1(1),195-461.

Silfianti. (2013). Kontribusi kompetensi manajerial kepala sekolah terhadap Training Need Assessment. Buletin Peneliti an Sistern Kesehatan, 9(4), 184-189.

Wahjosumidjo, (2008). Kepemimpinan Kepala Sekolah Tinjauan Teoritik dan Permasalahannya. Jakarta: Rajawaali Pers.

Yudani, N., I.N. Natajaya., K.R. Dantes. (2013). Kontribusi Gaya Kepemimpinan Kepala Sekolah, Kompetensi Profesional Dan Motivasi Kerja Terhadap Kinerja Guru Ips SeKabupaten Tabanan. e-Journal Program Pascasarjana Universitas Pendidikan Ganesha Program Studi Administrasi Pendidikan (Volume 4 Tahun 2013). 